\title{
Advanced Pancreatic Cancer: High-Intensity Focused Ultrasound (HIFU) and Other Local Ablative Therapies
}

\section{Fortgeschrittenes Pankreaskarzinom: Hoch-intensiver fokussierter Ultraschall (HIFU) und andere lokal ablative Verfahren}

Authors

Milka Marinova $^{1}$, Timo Wilhelm-Buchstab ${ }^{2 *}$, Holger Strunk ${ }^{1}$

Affiliations

1 Department of Radiology, Medical School \& Hospital, University of Bonn, Germany

2 Department of Radiology/Radiotherapy, Medical School \& Hospital, University of Bonn, Germany

Key words

abdomen, pancreas, ablation procedures, interventional procedures, ultrasound, adenocarcinoma

received 28.12 .2017

accepted 27.11.2018

\author{
Bibliography \\ DOI https://doi.org/10.1055/a-0820-5564 \\ Published online: 31.1.2019 \\ Fortschr Röntgenstr 2019; 191: 216-227 \\ (c) Georg Thieme Verlag KG, Stuttgart · New York \\ ISSN 1438-9029
}

\section{Correspondence}

PD Dr. med. Dr. rer. nat. Milka Marinova

Radiologische Klinik, Universitätsklinikum Bonn, Siegmund-Freud-Str. 25, D-53127 Bonn, Deutschland

Tel.: ++49/2 28/28711017

Fax: ++49/2 28/2879011017

milka.marinova@ukbonn.de

\section{ABSTRACT}

Background Locally advanced pancreatic cancer is a life-limiting tumor with a wide range of incapacitating symptoms such as cancer-associated pain. Several local ablative therapies with both thermal and non-thermal sources have recently received significant attention as modern treatment options for local tumor control and symptomatic improvement. The following review article provides an overview of currently available techniques and their outcomes including our own experience with high-intensity focused ultrasound (HIFU) being one of the most exciting and innovative modalities.

Method Our experiences with HIFU treatment are based on 89 pancreatic cancer patients (UICC III-IV). Outcomes such as treatment-related changes in symptoms particularly in cancer

contributed equally. pain and quality of life as well as local tumor response, safety and survival were compared to reported studies concerning HIFU, radiofrequency and microwave ablation, cryoablation, irreversible electroporation and stereotactic body radiation therapy.

Results Even though all strategies appeared to be feasible, the unique feature of noninvasiveness represents a substantial advantage of the HIFU procedure. In $85 \%$ of HIFU-treated patients, long-lasting pain relief was achieved. $50 \%$ of patients did not require any analgesic treatment 6 weeks post-ablation. Unfortunately, pain palliation and quality-of-life outcomes are only rarely reported for other local treatment modalities. Tumor mass reduction could be achieved with all ablative therapies, with a mean tumor volume reduction of $60 \%$ after 6 months in HIFU-treated pancreatic tumors. Differences in treatment-associated morbidity were reported. However, they are only partially comparable due to unbalanced study populations.

Conclusion Various local ablative treatment modalities are available and feasible for tumor mass reduction of advanced pancreatic cancer but with different symptomatic benefit for patients. An effective and long-lasting reduction of cancerrelated pain was observed following HIFU without insertion of needles or electrodes. Randomized controlled studies for head-to-head comparison of these modalities are warranted in the near future.

Key points:

- Several ablative therapies are available for the local treatment of inoperable pancreatic cancer.

- Tumor mass and symptom reduction are main goals of local therapies.

- HIFU differs based on its noninvasive approach and low complication rate.

- HIFU enables effective long-lasting pain relief in $>80 \%$ of patients.

- HIFU-associated pain relief is independent of tumor stage and metastatic status.

\section{Citation Format}

- Marinova M, Wilhelm-Buchstab T, Strunk H. Advanced Pancreatic Cancer: High-Intensity Focused Ultrasound (HIFU) and Other Local Ablative Therapies. Fortschr Röntgenstr 2019; 191: 216-227 


\section{ZUSAMMENFASSUNG}

Hintergrund Das lokal fortgeschrittene Pankreaskarzinom ist ein lebenslimitierender Tumor mit einer Vielzahl von Symptomen, u. a. Tumorschmerz. Lokal ablative Verfahren, die thermische oder auch nichtthermische Techniken anwenden, können als moderne Therapieoptionen zur Tumorkontrolle und symptomatischen Verbesserung eingesetzt werden. Dieser Artikel gibt einen Überblick über die derzeit verfügbaren Behandlungsverfahren und -ergebnisse, einschließlich unserer eigenen Erfahrungen mit dem hoch-intensiven fokussierten Ultraschall (HIFU).

Methode Unsere Erfahrungen mit der HIFU-Therapie beim Pankreaskarzinom basieren auf 89 Patienten (UICC III-IV). Neben den HIFU-Ergebnissen wurden Ergebnisse zur lokalen Tumorkontrolle, Sicherheit sowie Mortalität und behandlungsabhängigen Veränderung von Symptomen aus publizierten Studien zur Radiofrequenz-, Mikrowellen- und Kryoablation, irreversiblen Elektroporation und stereotaktischen Strahlentherapie einbezogen.

Ergebnisse Obwohl die unterschiedlichen Modalitäten überwiegend sicher durchführbar sind, bietet der HIFU mit seiner Nicht-Invasivität einen entscheidenden methodischen Vorteil.
Mit HIFU konnte bei $85 \%$ der Patienten eine effektive und langanhaltende Schmerzlinderung erreicht werden; bei $50 \%$ war nach 6 Wochen keinerlei analgetische Medikation erforderlich. Leider sind Schmerzlinderung und Lebensqualität bei den anderen lokalen Behandlungsmethoden nur selten untersucht. Eine Tumormassenreduktion konnte mit allen ablativen Therapien erreicht werden, wobei diese 6 Monate nach HIFU im Mittel bei $60 \%$ lag. Unterschiede in der behandlungsassoziierten Morbidität wurden berichtet, sind jedoch aufgrund der unausgewogenen Studienpopulationen nur eingeschränkt vergleichbar.

Schlussfolgerung Eine Vielzahl an lokal ablativen Behandlungsmodalitäten sind zur Tumormassenreduktion beim fortgeschrittenen Pankreaskarzinom verfügbar, bieten aber unterschiedlichen symptomatischen Nutzen. Eine effektive und langanhaltende Reduktion von Tumorschmerzen ohne Einführen von Nadeln oder Elektroden in den Tumorbereich bietet ausschließlich das HIFU-Verfahren. Randomisierte, kontrollierte klinische Studien zum direkten Vergleich der hier vorgestellten Modalitäten sind in der näheren Zukunft zu befürworten.

\section{Introduction}

More than $80 \%$ of patients with a ductal adenocarcinoma of the pancreas have an inoperable tumor at the time of diagnosis with a median survival time of only $4-6$ months and a 5 -year survival rate of less than $1 \%$ without treatment, thereby resulting in the worst prognosis among all gastrointestinal tumors. Despite new chemotherapy regimes, the 1-year survival rate continues to be only approximately $18-20 \%$. Moreover, chemotherapy has limited efficacy in local tumor control and the reduction of pain and symptoms. The quality of life in $80 \%$ of affected patients is limited by the main clinical symptom, i. e., tumor pain.

The goal of local therapies in pancreatic cancer is to prevent the growth of the primary tumor, and tumor-associated complications, as well as to alleviate symptoms. While radiotherapy is currently the most established local treatment method, additional local ablation methods have been used with good success in some cases in recent years. These methods include cryotherapy, radiofrequency ablation (RFA), microwave ablation (MWA), irreversible electroporation (IRE) and high-intensity focused ultrasound (HIFU) [1-6]. However, there are currently no comparative studies and the results are largely dependent on the experience of the particular surgeon or interventionalist. Ultrasound-guided HIFU is a minimally invasive and effective treatment option that can be successfully used in combination with palliative standard chemotherapy to reduce pain and provide local tumor control $[7,8]$ and in contrast to other local ablation methods, it does not involve the use of needles, probes, or electrodes. Based on our experience, the following overview article compares symptomatic therapy using US-guided HIFU in advanced pancreatic cancer to other local ablation methods.

\section{High-intensity focused ultrasound (HIFU)}

In HIFU, high-intensity US waves are bundled by special transducers and focused on a target point within the human body so that coagulation necrosis and tissue destruction are induced in the target tissue. Our experience with US-guided HIFU in advanced pancreatic cancer is based on the treatment of 89 patients with this tumor entity (UICC stage III-IV) in whom the clinical use of HIFU treatment in addition to palliative standard therapy was prospectively investigated [9-12]. Half of all patients who presented for local therapy fulfilled the requirements for being treated with this method. After HIFU ablation, the majority of patients (approx. $85 \%$ ) experienced effective and lasting pain reduction within the first week. The pain-reducing effect was related to the pain intensity as well as sensation of pain $[9,10,12,13]$ and was independent of the metastasis status. The effect on analgesic medication was evaluated based on changes in pain medication according to the WHO pain ladder (level I: non-opioid analgesics; level II: mild opioids with/without non-opioid analgesics; level III: strong opioids with/without non-opioid analgesics). A HIFU-associated increase in the number of patients at the low WHO levels 6 weeks after the intervention was observed with a simultaneous decrease in the number of patients at the higher WHO levels [11].

Tumor shrinkage occurred over time starting in the third week and was approx. $52 \% \pm 20 \%$ and $58 \% \pm 26 \%$ after 3 and 6 months, respectively, regardless of the disease stage $[9,10,12]$. After a median time of 14.4 months, tumor growth in the periphery of the previously treated tumor regions was observed in approx. $20 \%$ of patients and more than $60 \%$ of these patients successfully underwent a second HIFU treatment. Initially, there was arterial 
vessel involvement in $85 \%$ and venous vessel involvement in $95 \%$ of patients [14].

The median time between initial diagnosis and HIFU intervention was 6.8 months ( $0.4-34.7$ months). The median overall survival was 16.2 months from initial diagnosis and 8.3 months from HIFU intervention. Patients with UICC-III disease (approx. $40 \%$ ) had a longer median overall survival (25.6 months) than those with UICC-IV disease (approx. $60 \%$; 15.5 months). The progression-free survival rate was $93.1 \%$ after 6 months and $25.2 \%$ after 36 months. A median progression-free survival of 31.7 months was seen in patients with UICC-III disease and of 16.7 months in those with UICC-IV disease $(p<0.05)$. In this patient cohort, the leading cause of death was the progression of the tumor disease (progressive liver metastases, diffuse peritoneal carcinosis) in $82 \%$ of patients. The non-tumor-related causes of death included myocardial infarction, pulmonary embolism, and stroke ( $n=1$ in each case) as well as critical illness of infectious origin as a result of immunosuppression $(n=2)$. According to current knowledge, HIFU therapy is a low-risk interventional procedure with a low side effect rate when indications and contraindications are considered [15]. Apart from our study data, only fewer additional study results from Europe are available. This data is limited to two publications involving US-guided $(n=48)$ and MR-guided $(n=6)$ HIFU treatment of pancreatic cancer [16, 17]. Moreover, the efficacy of US-guided HIFU with a low rate of side effects has been described in many, primarily retrospective case series and reports from East Asia [18-26]. \ Table 1 provides a summary of the HIFU results [9, $16-18,21-25,27-31]$.

\section{Other location ablation methods}

In recent years various ablation treatment methods have been used for tumor mass reduction in patients with locally advanced pancreatic cancer without distant metastases, such as radiofrequency ablation (RFA), microwave ablation (MWA), cryotherapy, irreversible electroporation (IRE, NanoKnife ${ }^{\circledR}$ ) and stereotactic radiation therapy (Gamma-Knife ${ }^{\circledR}$, CyberKnife ${ }^{\circledR}$ ) [32 - 36]. Photodynamic therapy (PDT) and electrochemotherapy (ECT) are used less frequently. The therapeutic effects of these palliative treatment approaches are associated with the induction of intralesional necrosis, cytolysis, and cell death ultimately resulting in tumor cytoreduction. Some studies describe an additional increase in the tumor-induced immune response after ablation [37]. The various techniques can be divided into two main groups: (1) Methods using thermal ablation; (2) Methods using non-thermal ablation that cause direct damage to neoplastic cells. Many of the techniques can be performed during an operation via laparotomy or laparoscopy as well as via percutaneous or endoscopic access. The most commonly used methods are discussed in detail in the following.

\section{Radiofrequency ablation (RFA)}

Radiofrequency ablation causes coagulation necrosis and tissue damage due to high, locally applied temperatures (up to $90^{\circ} \mathrm{C}$ in pancreatic cancer) generated by a high-frequency alternating current. RFA is highly valuable in the treatment of hepatocellular carcinoma and is part of the standard therapy for this tumor entity. Due to the retroperitoneal location of the pancreas which makes the organ difficult to access, RFA in pancreatic cancer is typically performed via an open surgical access with intraoperative US control. In the case of good accessibility of the tumor, RFA can be performed percutaneously in rare cases and endoscopically in individual cases. Percutaneous and endoscopic ablation can be performed under local anesthesia and sedation. Appropriate access route, needle type, and electrode opening are selected depending on tumor location, configuration, and size. A safety distance of approx. $5 \mathrm{~mm}$ between the tip of the electrode needle and risk structures, such as peripancreatic vessels, should usually be maintained. D Table 2 summarizes results of RFA studies in locally advanced pancreatic cancer [33, $38-44]$.

With respect to the use of RFA in pancreatic cancer, some interesting additional findings have been described previously. On the one hand, it was reported that vital tumor parts in the periphery of the treated region that remained untreated to prevent thermal damage to surrounding risk structures were also partially damaged which may possibly increase the immune response by potentially recruiting immune cells [45]. On the other hand, early disease progression was seen in patients who were initially treated with RFA. This was not the case for patients treated with neoadjuvant chemotherapy and subsequent local RFA as a secondary treatment [41].

\section{Microwave ablation (MWA)}

Microwaves heat a material by causing water molecules to vibrate thus generating friction and heat and inducing cell death via coagulation necrosis. In contrast to an electrical current, microwaves can spread through biological tissue types with a high impedance. Consequently heat can be generated in greater tissue volumes. For this reason, the use of microwaves can result in faster and greater ablation with higher temperatures than with RFA. MWA can be performed via percutaneous endoscopic, laparoscopic, or open surgical access. Consequently, either analog sedation or general anesthesia of the patient is necessary. The location of the target lesion is usually determined under either US or CT guidance.

Only a few data regarding MWA in pancreatic cancer is currently available ( $\triangleright$ Table 3$)[46,47]$.

\section{Cryoablation}

Cryoablation is based on the destruction of tumor cells by means of cold and intracellular and extracellular freezing that causes direct cell damage via the quick formation of ice crystals leading to cell death. Furthermore, slower tissue freezing favors the formation of ice crystals in the extracellular space with a change in osmolarity resulting in cell dehydration with subsequent cell death. The low temperature needed for cell death and applied 
- Table 1 High-intensity focused ultrasound (HIFU) in pancreatic cancer.

\begin{tabular}{|c|c|c|c|c|c|c|}
\hline reference & $\begin{array}{l}\text { number } \\
\text { of patients }\end{array}$ & access & pain reduction & quality of life & morbidity & median survival \\
\hline Anzidei et al. [16] & 6 & MR guidance & $83 \%$ & not reported & not reported & not reported \\
\hline Gao et al. [18] & 39 & US guidance & $\begin{array}{l}79.5 \% \\
\text { complete } 23.1 \% \\
\text { partial } 56.4 \%\end{array}$ & not reported & $12.8 \%$ & 11 months \\
\hline Li et al. [21] & 25 & US guidance & $92 \%$ & not reported & not reported & 10 months \\
\hline Marinova et al. [9] & 50 (19 III) & US guidance & $84 \%$ & $\begin{array}{l}\uparrow \text { no further } \\
\text { details }\end{array}$ & $<10 \%$ & $\begin{array}{l}16.2 \text { months } \\
8.3 \text { months after } \\
\text { HIFU }\end{array}$ \\
\hline Orsi et al. [27] & 6 & US guidance & $75 \%$ & $\begin{array}{l}\uparrow \text { no further } \\
\text { details }\end{array}$ & not reported & 7 months after HIFU \\
\hline Sofuni et al. [28] & 30 (16 III) & US guidance & $66.7 \%$ & $\begin{array}{l}\uparrow \text { no further } \\
\text { details }\end{array}$ & $10 \%$ & not reported \\
\hline Sung et al. [22] & 46 & US guidance & $>60 \%$ & not reported & $10.9 \%$ & $\begin{array}{l}12.4 \text { months } \\
7 \text { months after HIFU }\end{array}$ \\
\hline Vidal-jove et al. [17] & 43 & US guidance & not reported & not reported & $11.3 \%$ & 12.5 months \\
\hline Wang et al. [23] & 40 (13 III) & US guidance & $\begin{array}{l}87.5 \% \\
\text { complete } 22.5 \% \\
\text { partial } 65 \%\end{array}$ & not reported & not reported & 10 months \\
\hline Wang et al. [24] & 224 (86 III) & US guidance & not reported & not reported & $5.8 \%$ & not reported \\
\hline Wu et al. [25] & 8 (3 III) & US guidance & $100 \%$ & $\begin{array}{l}\uparrow \text { no further } \\
\text { details }\end{array}$ & not reported & 11.3 months \\
\hline Xiong et al. [29] & 89 (39 III) & US guidance & $78.6 \%$ & not reported & $11.2 \%$ & 11.2 months \\
\hline Zhao H. et al. [30] & 39 (31 III) & US guidance & $\begin{array}{l}78.6 \% \\
\text { complete } 32.2 \% \\
\text { partial } 46.4 \%\end{array}$ & not reported & $\begin{array}{l}\text { no further } \\
\text { details }\end{array}$ & 12.6 months \\
\hline Zhao J. et al. [31] & $38 \mathrm{III}$ & US guidance & not reported & not reported & $<25 \%$ & 10.3 months \\
\hline
\end{tabular}

- Table 2 Selected studies on radiofrequency ablation (RFA) in pancreatic cancer.

\begin{tabular}{|c|c|c|c|c|c|c|}
\hline reference & $\begin{array}{l}\text { number of } \\
\text { patients }\end{array}$ & access & pain reduction & quality of life & morbidity & median survival \\
\hline Cantore et al. [38] & 107 & surgical (via laparotomy) & not reported & not reported & $28 \%(n=30)$ & 25.6 months \\
\hline D'Onforio et al. [33] & 18 & percutaneous with US guidance & not reported & not reported & not reported & not reported \\
\hline Frigerio et al. [39] & 57 & not reported & not reported & not reported & $14 \%(n=18)$ & 19 months \\
\hline Girelli et al. [40] & 50 & $\begin{array}{l}\text { surgical (via laparotomy) with } \\
\text { US guidance }\end{array}$ & $69 \%$ & not reported & $24 \%(n=12)$ & not reported \\
\hline Girelli et al. [41] & 100 & $\begin{array}{l}\text { surgical (via laparotomy) with } \\
\text { US guidance }\end{array}$ & not reported & not reported & $24 \%(n=24)$ & 20 months \\
\hline Matsui et al. [42] & 20 & surgical (via laparotomy) & not reported & not reported & $10 \%$ & 5 months \\
\hline Spiliotis et al. [43] & 12 & surgical with US guidance & not reported & not reported & not reported & $13-19$ months \\
\hline Wu et al. [44] & 16 & surgical & $(50 \%)$ & not reported & $19 \%$ & not reported \\
\hline
\end{tabular}


- Table 3 Selected studies on microwave ablation (MWA) in pancreatic cancer.

\begin{tabular}{|l|l|l|l|l|l|l|}
\hline reference & $\begin{array}{l}\text { number of } \\
\text { patients }\end{array}$ & access & pain reduction & quality of life & morbidity \\
\hline Carrafiello et al. [46] & 10 & $\begin{array}{l}\text { percutaneous }(n=5) \\
\text { surgical (laparotomy) } \\
(\mathbf{n}=5)\end{array}$ & not reported & $\uparrow$ no further details & $20 \%$ & not reported \\
\hline Lygidakis et al. [47] & 15 & surgical (laparotomy) & not reported & not reported & $29 \%$ & not reported \\
\hline
\end{tabular}

- Table 4 Cryoablation in pancreatic cancer.

\begin{tabular}{|c|c|c|c|c|c|c|}
\hline reference & $\begin{array}{l}\text { number of } \\
\text { patients }\end{array}$ & access & pain reduction & quality of life & morbidity & median survival \\
\hline Li et al. [49] & 68 & surgical & not reported & not reported & $\begin{array}{l}\text { no significant difference with } \\
\text { respect to the control group } \\
\text { except for delayed gastric } \\
\text { emptying (approx. } 36 \% \text { vs. } 5 \% \text { ) }\end{array}$ & 350 days \\
\hline Song et al. [50] & $\begin{array}{l}46 \text { ( } 72 \text { control } \\
\text { group) }\end{array}$ & surgical & not reported & $\begin{array}{l}\uparrow \text { no further } \\
\text { details }\end{array}$ & $\begin{array}{l}\text { no significant difference with } \\
\text { respect to the control group }\end{array}$ & 5 months \\
\hline
\end{tabular}

via a needle-like cryoprobe varies (between $-35^{\circ} \mathrm{C}$ and $-20^{\circ} \mathrm{C}$ ). Multiple cryoprobes are often needed to achieve sufficient ablation which is also associated with a longer treatment time (approx. 25-30 min). After the procedure, cellular components are not infrequently released into the circulation so that systemic complications like cryoshock can occur. Cryoablation with intraoperative US guidance is used most frequently. Percutaneous access with US or CT guidance is also possible in selected cases [48]. Larger tumors $(>3 \mathrm{~cm})$ usually require multiple probes or multiple ablation procedures. At present, fewer data regarding cryoablation in pancreatic cancer is available ( Table 4). [49, 50].

\section{Irreversible electroporation (IRE)}

Irreversible electroporation (Nano-Knife ${ }^{\circledR}$ ) is a non-thermal ablation method and can be used for treating locally advanced pancreatic cancer. The ablative effect with the subsequent induction of cell death is based on the use of short pulses of strong electrical fields that induce nanometer-sized pores in cell membranes thereby causing cell damage. In contrast to the other minimally invasive ablation methods, IRE disrupts cellular homeostasis and induces cell death by apoptosis. A theoretical advantage of IRE is that the surrounding risk structures, such as nerves and vessels, can be protected. However, this has not been confirmed by practical use. For example, acute portal vein thrombosis $(n=3)$ and splenic vein thrombosis $(n=1)$ have been observed, after $\mathrm{CT}$-guided percutaneous IRE in 50 patients with locally infiltrative pancreatic cancer [51].

In the case of a high current intensity, this technique can also cause some thermal damage thus inducing coagulation necrosis in the tissue as in the case of RFA or MWA. IRE probes are thinner but significantly more expensive than RFA or MWA probes, for example. IRE is performed in most cases as part of a surgery with the electrodes being placed within the target lesion. In addition to the palliative approach to tumor mass reduction, this method is also used for downstaging with subsequent surgery.

- Table 5 provides an overview of selected IRE studies in pancreatic cancer patients [35, $51-57]$.

\section{Stereotactic radiotherapy}

In stereotactic radiotherapy (stereotactic body radiation therapy, SBRT) usually in combination with systemic therapy (gemcitabine), targeted high-energy photons induce cell destruction in the tumor region. Ionizing radiation results in the formation of highly toxic radicals that damage the genetic material of the cells causing apoptosis. However, the method should be restricted to locally advanced tumors $(<5 \mathrm{~cm})$. High-precision accelerators are used, such as CyberKnife ${ }^{\circledR}$ and GammaKnife ${ }^{\circledR}$, or accelerators from various manufacturers with micro-multileaf collimators (True beam ${ }^{\circledR}$, Novalis ${ }^{\circledR}$ Radiosurgery, etc.) which have the necessary radiation modulation capability and resulting beam accuracy and can be combined in some cases.

A particular difficulty with respect to SBRT of pancreatic tumors is the mobility of the pancreas. Even normal breathing can result in displacement of the tumor of up to $3 \mathrm{~cm}$ due to movement of the diaphragm. This should be taken into consideration in radiation treatment planning to avoid insufficient dose deposition in the periphery of the target volume and a radiation overdose in surrounding organs. As in the case of tumors of the lung, liver or other moving organs, motion tracking or respiratory gating in which gold markers (seeds) previously placed in or 
- Table 5 Studies on irreversible electroporation (IRE) in pancreatic cancer.

\begin{tabular}{|c|c|c|c|c|c|c|}
\hline reference & $\begin{array}{l}\text { number of } \\
\text { patients }\end{array}$ & access & pain reduction & quality of life & morbidity & median survival \\
\hline Belfiore et al. [52] & 29 & $\begin{array}{l}\text { percutaneous } \\
\text { with } C T \text { guidance }\end{array}$ & not reported & $\begin{array}{l}\uparrow \text { no further } \\
\text { details }\end{array}$ & not reported & 14 months \\
\hline Dunki-Jacobs et al. [53] & 65 & $\begin{array}{l}\text { percutaneous }(n=12) \\
\text { surgical }(n=53)\end{array}$ & not reported & not reported & $\begin{array}{l}\text { high, no further } \\
\text { details }\end{array}$ & Not reported \\
\hline Kluger et al. [54] & 50 & surgical & not reported & not reported & high (up to $30 \%$ ) & 12.03 months \\
\hline Mansson et al. [55] & 24 & $\begin{array}{l}\text { percutaneous } \\
\text { with US guidance }\end{array}$ & not reported & not reported & $64 \%$ & $\begin{array}{l}17.9 \text { months, } \\
7 \text { months after IRE }\end{array}$ \\
\hline Martin et al. [56] & 200 & $\begin{array}{l}\text { surgical } \\
\text { with intraoperative US } \\
\text { guidance }\end{array}$ & not reported & not reported & $37 \%$ & 24.9 months \\
\hline Narayanan et al. [51] & 50 & $\begin{array}{l}\text { percutaneous } \\
\text { with CT guidance }\end{array}$ & not reported & not reported & $42 \%$ & $\begin{array}{l}27 \text { months, } \\
14.2 \text { months after } \\
\text { IRE }\end{array}$ \\
\hline Scheffer et al. [35] & 25 & $\begin{array}{l}\text { percutaneous } \\
\text { with } \mathrm{CT} \text { guidance }\end{array}$ & $\begin{array}{l}\text { none } \\
\text { increase in } \\
\text { pain }\end{array}$ & $\begin{array}{l}\text { partial } \downarrow \text { or } \\
\text { no change }\end{array}$ & $40 \%$ & $\begin{array}{l}17 \text { months, } \\
11 \text { months after } \\
\text { IRE }\end{array}$ \\
\hline Yan et al. [57] & 25 & $\begin{array}{l}\text { surgical } \\
\text { with intraoperative US } \\
\text { guidance }\end{array}$ & not reported & not reported & $36 \%$ & Not reported \\
\hline
\end{tabular}

US: Ultrasound.

around the tumor are used to detect the target region during image-guided treatment to improve beam accuracy.

Despite the noninvasiveness of SBRT, both acute gastrointestinal side effects (nausea, vomiting, tenesmus) and delayed reactions (mucosal ulcerations, strictures, duodenal perforation) have been reported due to the close proximity to neighboring risk organs. The method is limited by the extent of the tumor to be treated and the tolerance of the surrounding risk structures such as the stomach and the small intestine so that it is difficult to define a standardized dose scheme. Individual fractionated doses between 6 and $25 \mathrm{~Gy}$ are described in various fractionation schemes in the literature. However, the ability to compare the patient populations is limited. Most studies ( $\vee$ Table 6 ) report a median overall survival rate between 10 and 20 months, but information regarding quality of life and pain control is provided in only a few studies [58 - 73].

\section{Discussion}

For the local treatment of inoperable pancreatic cnacer various local ablation methods have become more popular in recent years in order to reduce symptoms by causing local tumor destruction, to prevent progression of the disease, and to improve the survival rate of patients [6, $74-76]$. The main advantages and disadvantages of these treatment options are summarized in $>$ Table 7. A direct comparison of the various local ablation procedures is currently not possible since the published studies have been performed with differently defined and unbalanced patient populations and indications and controlled comparative studies are currently not available.

Data regarding the clinical use of radiofrequency and microwave ablation, irreversible electroporation, cryoablation, radiotherapy and high-intensity focused ultrasound indicate that this procedures can be used relatively safely for (temporary) local tumor control of inoperable pancreatic cancer. As a result of the thinner electrodes and the non-thermal mechanism of action, IRE may have an advantage with respect to the protection of neighboring large vessels and nerves. However, this has not yet been definitively proven in studies. Apart from stereotactic radiation, HIFU is currently the only one of the local ablation methods described above that does not involve the use of needles, electrodes, probes, or similar [77, 78]. Therefore, HIFU treatment can even be performed in patients with tumors in the direct vicinity of vessels, the bowel, or a biliary stent. In addition, potential complications caused by puncture, particularly bleeding (e. g. in the case of extensive collateral vessels in tumors obstructing the mesenteric veins) or seeding metastases in the puncture channel, are not an issue in the case of HIFU. Surgical access is usually selected for the other local ablation methods. For example, in the largest treatment series to date including 200 patients undergoing IRE, 149 complications were described in 74 patients (37\%), including $5.5 \%$ vascular complications, when differentiation between IRE-related complications and those caused by surgical access seems to be very difficult [56]. Although stereotactic radiotherapy based on the intratumoral administration of radiation using advanced image guidance techniques is slightly 
- Table 6 Selected studies on stereotactic radiotherapy in pancreatic cancer.

\begin{tabular}{|c|c|c|c|c|c|c|}
\hline reference & $\begin{array}{l}\text { number of } \\
\text { patients }\end{array}$ & dose/fraction (Gy) & local control (\%) & quality of life & morbidity & median survival \\
\hline Algappan et al. [58] & 208 & $\begin{array}{l}12.5-25 n=103 \\
25-45 \\
\text { in } 5 \text { fractions } \\
n=105\end{array}$ & 88.5 & not reported & not reported & 14 months \\
\hline Chuong et al. [59] & 73 & $25-35$ in 5 fractions & 81 & not reported & $\begin{array}{l}\text { fatigue } \\
\text { grade III: } 3\end{array}$ & 15 months \\
\hline Comito et al. [60] & 43 & 45 in 6 fractions & 90 & not reported & $\begin{array}{l}\text { fatigue: } 16 \\
\text { acute GI side } \\
\text { effects: } \\
\text { grade I-II: } 5 \\
\text { late GI side effects: } \\
\text { grade II: } 2\end{array}$ & 19 months \\
\hline Dholakia et al. [61] & 32 & 33 in 5 fractions & not reported & not reported & not reported & 18.8 months \\
\hline Gurka et al. [62] & 10 & 25 in 5 fractions & not reported & $\begin{array}{l}\text { no significant } \\
\text { pain reduction }\end{array}$ & $\begin{array}{l}\text { acute GI side } \\
\text { effects: } \\
\text { grade I-II: } 11 \\
\text { late GI side effects: } \\
\text { grade I: } 1\end{array}$ & 12.2 months \\
\hline Herman et al. [63] & 49 & 33 in 5 fractions & 78 & $\begin{array}{l}\text { significant pain } \\
\text { reduction }\end{array}$ & $\begin{array}{l}\text { minimal GI side } \\
\text { effects: Grade I-II }\end{array}$ & 13.9 months \\
\hline Hoyer et al. [64] & 22 & 25 in 3 fractions & 57 & not reported & & 5.7 months \\
\hline Koong et al. [65] & 15 & $\begin{array}{l}15 n=3 \\
20 n=5 \\
25 n=7\end{array}$ & 100 & not reported & $\begin{array}{l}\text { no significant Gl } \\
\text { side effects }\end{array}$ & 11 months \\
\hline Mahadevan et al. [66] & 36 & $24-36$ in 3 fractions & 78 & not reported & $\begin{array}{l}\text { Gl side effects } \\
\text { grade I: } 15 \\
\text { grade II: } 9 \\
\text { grade III: } 3\end{array}$ & 14.3 months \\
\hline Mahadevan et al. [67] & 39 & $24-36$ in 3 fractions & 85 & not reported & $\begin{array}{l}\text { grade II: } 9 \\
\text { grade III: } 3\end{array}$ & 20 months \\
\hline Rwigema et al. [68] & 71 & $\begin{array}{l}25 n=5 \\
24 n=43 \\
22 n=13 \\
20 n=4 \\
18 n=2 \\
\text { fractionated } n=4\end{array}$ & $\begin{array}{l}57.5-77.3 \\
\leq \text { vs. } \geq 15 \mathrm{ml} \text { tumor } \\
\text { volume }\end{array}$ & not reported & $\begin{array}{l}\text { acute GI side } \\
\text { effects: } \\
\text { grade I: } 17 \\
\text { grade II: } 8 \\
\text { grade III: } 3 \\
\text { late GI side effects: } \\
\text { grade I: } 3\end{array}$ & 10.3 months \\
\hline Schellenberg et al. [69] & 16 & 25 & 81 & not reported & $\begin{array}{l}\text { mild acute side } \\
\text { effects } \\
\text { late GI side effects: } \\
\text { grade II: } 5 \\
\text { grade III: } 1 \\
\text { grade IV: } 1\end{array}$ & 11.4 months \\
\hline Schellenberg et al. [70] & 20 & 25 & 81 & not reported & $\begin{array}{l}\text { GI side effects } \\
\text { grade I: } 18 \\
\text { grade II: } 3 \\
\text { late side effects: } \\
\text { grade IV: } 1\end{array}$ & 11.8 months \\
\hline Song et al. [71] & 59 & $\begin{array}{l}35-50 \text { in } \\
3-8 \text { fractions }\end{array}$ & 90 & not reported & $\begin{array}{l}\text { acute/late GI side } \\
\text { effects: } \\
\text { grade I-II: } 61 \% \\
\text { late GI side effects: } \\
\text { grade III: } 1\end{array}$ & 12.5 months \\
\hline
\end{tabular}


- Table 6 (Continuation)

\begin{tabular}{|l|l|l|l|l|l|}
\hline reference & $\begin{array}{l}\text { number of } \\
\text { patients }\end{array}$ & dose/fraction (Gy) & local control (\%) & quality of life & morbidity \\
\hline Tozzi et al. [72] & 30 & $36-45$ in 6 fractions & 86 & pain reduction & $\begin{array}{l}\text { median survival } \\
\text { fatigue: } 12 \\
\text { acute Gl side } \\
\text { effects: } \\
\text { grade I: } 5 \\
\text { grade II: } 3\end{array}$ \\
\hline Zhu et al. [73] & 417 & $\begin{array}{l}30-46 \\
8 \text { in } 5-8 \text { fractions }\end{array}$ & not reported & not reported & $\begin{array}{l}\text { mild Gl side effects } \\
\text { grade I-II } \\
\text { grade III: } 1\end{array}$ \\
\hline
\end{tabular}

less invasive, the reported rate of side effects is similarly high with a relatively high number of late complications.

All of the discussed local ablation methods are currently only considered in the case of inoperable tumors. If such a situation is detected on the basis of pretherapeutic imaging, it may be questionable if a surgical intervention for probe placement is indicated when the results do not provide a convincing advantage. However, intraoperative local tumor ablation, e. g. via IRE, could be indicated in the case of a tumor that is assumed to be locally operable but then proves to be unresectable during surgical procedure.

However, the greatest clinical relevance of local ablation methods may be the symptomatic benefit as shown particularly for HIFU therapy. Both effective and lasting tumor-associated pain reduction was achieved in the majority of patients with advanced pancreatic cancer (75-80\%). Other available pain-reduction options are either of short duration (e.g. celiac plexus block) or have numerous side effects (e.g. opioids). Both pain intensity and pain sensation were significantly reduced after HIFU regardless of the tumor stage and the presence of distant metastases. The pain-reducing effect was already observed in the first week after therapy in some cases, i. e., significantly earlier than any identifiable tumor shrinkage [10, 11, 31 - 39]. The early pain reduction achieved by HIFU apparently precedes tumor shrinkage. One possible explanation for this is the destruction of local nociceptive nerve fibers in the ablation region, resulting in a reduction of central nociceptive sensitivity [13, 31 - 39]. In addition pain caused by the compression of surrounding structures is reduced by a subsequent tumor shrinkage, resulting in a further reduction of the pain level. The pain relief achieved by HIFU had a long-term effect that lasted for months. However, local HIFU treatment cannot be used for every pancreatic tumor. For example, the tumor must be able to be visualized on ultrasound and be at a depth of no more than approximately $12 \mathrm{~cm}$. Moreover, no large calcifications or surgical clips should be present in the target region since they can cause potentially dangerous scattering of the sound waves.
To date, pain reduction by RFA has only be reported in one study (in $69 \%$ of patients) [40]. To our knowledge, effects on quality of life have not yet been described in any study (even though multiple current studies can be found under ClinicalTrials.gov). The extent to which symptom improvement can be achieved with the other local ablation methods cannot be determined from the literature. In fact, symptom worsening was even reported in one study following IRE [35].

With respect to survival, local ablation methods may provide additional advantages for patients with advanced pancreatic cancer even if this effect has not yet been proven. On the whole, a longer median survival was reported in patients treated with RFA, IRE, and radiation compared to patients treated with HIFU $(\triangleright$ Table $1,2,5)$. This can be partly explained by the fact that RFA and IRE are primarily used in patients with locally advanced disease but without distant metastases and sometimes in operable tumors. In comparison, HIFU was used in Germany in patients with contraindications for surgery, in advanced tumor stages and with distant metastases in approximately $60 \%$ of cases. The median overall survival of 16.2 months from initial diagnosis and 8.3 months from HIFU intervention indicates a positive prognostic tendency with a longer survival compared to previously published results (10-13 months from initial diagnosis, $6-8.4$ months for patients with UICC-IV disease [17, 22, 23]).

Since HIFU therapy does not interact negatively with standard palliative therapy and is a low-risk interventional procedure with few transient side effects, chemotherapy can be continued without interruption. Even without chemotherapy, e. g. when not tolerated (approx. $10 \%$ of cases), a significant tumor volume reduction could be observed in the postinterventional course after HIFU ablation alone. The median overall survival for patients undergoing only chemotherapy/radiochemotherapy is 6.211 months. In the advanced stage (UICC IV), this time is shortened to $6.2-8.4$ months and without any tumor-oriented therapy even to 1.1 months [79]. In our patient population, a median progression-free survival of 16.9 months from initial diagnosis and of 6.8 months after HIFU intervention was seen, both of which are longer than with palliative chemotherapy alone (3.4 - 5.5 months). 
- Table 7 Overview of the advantages and disadvantages of the various local ablation methods in pancreatic cancer.

\begin{tabular}{|c|c|c|}
\hline technique & advantages & disadvantages \\
\hline US-guided HIFU & $\begin{array}{l}\text { - } \text { noninvasive, repeatable } \\
\text { - US guidance with anatomical real-time imaging } \\
\text { - } \text { no needles, electrodes, probes needed, therefore no } \\
\text { seeding of tumor cells and no risk of puncture-associated } \\
\text { bleeding } \\
\text { - } \text { no ionizing radiation } \\
\text { - precise local ablation } \\
\text { - very effective pain reduction technique } \\
\text { - usually short hospital stay ( } 1 \text { - } 3 \text { days) } \\
\text { - good protection of surrounding risk structures } \\
\text { - low-risk method with a low complication rate } \\
\text { - can be combined with other methods } \\
\text { - possible HIFU-based immune modulation }\end{array}$ & $\begin{array}{l}\text { - limited availability } \\
\text { - long treatment time ( } 1-4 \text { hours) depending on the } \\
\text { size and location of the tumor } \\
\text { - general anesthesia or analog sedation required } \\
\text { - adequate acoustic window needed, no US access } \\
\text { behind gas-filled organs } \\
\text { - no histological specimen } \\
\text { - not possible to explore the peritoneal cavity } \\
\text { - } \text { specific bowel preparation required prior to therapy } \\
\text { - skin burns/damage ( } 0.4-1 \%) \\
\text { - inpatient treatment required }\end{array}$ \\
\hline RFA & $\begin{array}{l}\text { " theoretically broad availability } \\
\text { " possible to explore the peritoneal cavity with open } \\
\text { surgical access } \\
\text { " possible RFA-based immune modulation }\end{array}$ & $\begin{array}{l}\text { - tumor debulking possible on a limited basis with } \\
\text { safety distance from risk structures (upper abdominal } \\
\text { vessels, bile ducts) being required } \\
\text { - } \text { reduced treatment efficacy due to heat-sink effect } \\
\text { near large vessels } \\
\text { - relatively high complication rate (up to } 28 \% \text { ) } \\
\text { - primarily open surgical approach, percutaneous } \\
\text { access rarely possible } \\
\text { - radiation exposure during CT-guided probe } \\
\text { - incement }\end{array}$ \\
\hline MWA & $\begin{array}{l}\text { - possible to explore the peritoneal cavity with open } \\
\text { surgical access } \\
\text { - faster ablation possible (than for example with RFA) }\end{array}$ & $\begin{array}{l}\text { - limited availability } \\
\text { - primarily open surgical approach, percutaneous } \\
\text { access rarely possible } \\
\text { - limited data regarding use in pancreatic cancer } \\
\text { - radiation exposure during CT-guided probe } \\
\text { placement } \\
\text { - inpatient treatment required }\end{array}$ \\
\hline cryoablation & $\begin{array}{l}\text { - suspected abscopal effect particularly in combination } \\
\text { with immune therapy }\end{array}$ & $\begin{array}{l}\text { - limited availability } \\
\text { - cryoshock syndrome } \\
\text { - } \text { hemorrhages due to tears caused by ice crystals } \\
\text { - intraoperative access needed for larger probes } \\
\text { - no survival advantage of cryoablation described } \\
\text { to date } \\
\text { - minimal available data } \\
\text { - inpatient treatment required }\end{array}$ \\
\hline IRE & $\begin{array}{l}\text { - use of primary tumor control after resection } \\
\text { - repeatable } \\
\text { " possible in the vicinity of critical structures } \\
\text { (bile ducts, large blood vessels) } \\
\text { - not susceptible to heat-sink effect } \\
\text { - exploration of the peritoneal cavity possible during } \\
\text { intraoperative use } \\
\text { - theoretically broad availability }\end{array}$ & $\begin{array}{l}\text { - no standardized protocol } \\
\text { - high complication rate (up to } 30 \% \text { ) } \\
\text { - inpatient treatment required }\end{array}$ \\
\hline radiation & $\begin{array}{l}\text { - usually noninvasive } \\
\text { - outpatient treatment possible }\end{array}$ & $\begin{array}{l}\text { - } \text { multiple treatment cycles } \\
\text { - } \text { no standardized data regarding radiation dose } \\
\text { - } \text { repeated treatment usually not possible } \\
\text { - lower dose at the tumor borders to protect } \\
\text { neighboring risk organs } \\
\text { - } \text { relatively high complication rate (up to } 29 \% \text { ) } \\
\text { - } \text { risk for late complications (>3 months) }\end{array}$ \\
\hline
\end{tabular}




\section{Conclusion}

A number of local ablation treatment options are available for tumor mass reduction in locally advanced pancreatic cancer. Even though these ablation procedures are all largely safe, HIFU has a decisive advantage in its non-invasiveness. At present, the greatest clinical and symptomatic benefit of HIFU treatment is referred to significant pain reduction since most patients with advanced disease and progressive tumor pain have exhausted the pain therapy options. However, to date, the use of local ablation procedures in pancreatic cancer has been investigated only insufficiently so that randomized controlled comparative studies are urgently needed.

\section{Conflict of Interest}

The authors declare that they have no conflict of interest.

\section{Dedication}

Diese Übersichtsarbeit widmen wir Herrn Univ.-Prof. Dr. med. Hans H. Schild, bei dem wir uns ganz herzlich für die langjährige und stete Unterstützung in allen klinischen und wissenschaftlichen Belangen bedanken möchten.

\section{References}

[1] Goldberg SN, Gazelle GS, Mueller PR. Thermal ablation therapy for focal malignancy: a unified approach to underlying principles, techniques, and diagnostic imaging guidance. American journal of roentgenology 2000; 174: 323-331

[2] Kovach SJ, Hendrickson RJ, Cappadona CR et al. Cryoablation of unresectable pancreatic cancer. Surgery 2002; 131: $463-464$

[3] Sato M, Watanabe $Y$, Kashu $Y$ et al. Sequential percutaneous microwave coagulation therapy for liver tumor. American journal of surgery 1998; 175: $322-324$

[4] Varshney S, Sewkani A, Sharma S et al. Radiofrequency ablation of unresectable pancreatic carcinoma: feasibility, efficacy and safety. JOP: Journal of the pancreas 2006; 7: 74-78

[5] Dale PS, Souza JW, Brewer DA. Cryosurgical ablation of unresectable hepatic metastases. Journal of surgical oncology 1998; 68: 242-245

[6] Keane MG, Bramis K, Pereira SP et al. Systematic review of novel ablative methods in locally advanced pancreatic cancer. World journal of gastroenterology: WJG 2014; 20: 2267-2278

[7] Marinova M, Rauch M, Mucke M et al. High-intensity focused ultrasound (HIFU) for pancreatic carcinoma: evaluation of feasibility, reduction of tumour volume and pain intensity. Eur Radiol 2016. doi:101007| s00330-016-4239-0

[8] Strunk HM, Henseler J, Rauch M et al. Klinischer Einsatz des hoch-intensiven fokussierten Ultraschalls (HIFU) zur Tumor- und Schmerzreduktion bei fortgeschrittenem Pankreaskarzinom. Clinical use of high-intensity focused ultrasound (HIFU) for tumor and pain reduction in advanced pancreatic cancer. Fortschr Röntgenstr 2016; 188: 1-9 ahead of print DOI http://dxdoiorg/101055/s-0042-105517 2016

[9] Marinova M, Huxold HC, Henseler J et al. Clinical effectiveness and potential survival benefit of US-guided high-intensity focused ultrasound in patients with advanced pancreatic cancer. Ultraschall in Med, ahead of print 2018

[10] Marinova M, Rauch M, Mucke M et al. High-intensity focused ultrasound (HIFU) for pancreatic carcinoma: evaluation of feasibility, reduction of tumour volume and pain intensity. European radiology 2016; 26: 4047 4056

[11] Marinova M, Strunk HM, Rauch M et al. High-intensity focused ultrasound (HIFU) for tumor pain relief in inoperable pancreatic cancer: Evaluation with the pain sensation scale (SES). Schmerz 2016. doi:10.1007/s00482-016-0140-7

[12] Strunk HM, Henseler J, Rauch M et al. Clinical Use of High-Intensity Focused Ultrasound (HIFU) for Tumor and Pain Reduction in Advanced Pancreatic Cancer. Rofo 2016; 188: 662-670

[13] Marinova M, Strunk HM, Rauch M et al. Hoch-intensiver fokussierter Ultraschall (HIFU) zur Linderung tumorbedingter Schmerzen bei inoperablem Pankreaskarzinom: Evaluation anhand der Schmerzempfindungsskala (SES). [High-intensity focused ultrasound (HIFU) for tumor pain relief in inoperable pancreatic cancer: Evaluation with the pain sensation scale (SES)]. Schmerz 2016. doi:10.1007/s00482-016-0140-7

[14] Strunk HM, Lützow C, Henseler J et al. Mesenteric vessel patency following HIFU-therapy in patients with locally invasive pancreatic cancer. Ultraschall in Medzin/European Journal of Ultrasound, accepted/in print 2017

[15] Yu T, Luo J. Adverse events of extracorporeal ultrasound-guided high intensity focused ultrasound therapy. PloS one 2011; 6: e26110. doi:10.1371/journal.pone.0026110

[16] Anzidei M, Marincola BC, Bezzi M et al. Magnetic resonance-guided highintensity focused ultrasound treatment of locally advanced pancreatic adenocarcinoma: preliminary experience for pain palliation and local tumor control. Investigative radiology 2014; 49: 759-765

[17] Vidal-Jove J, Perich E, del Castillo MA. Ultrasound Guided High Intensity Focused Ultrasound for malignant tumors: The Spanish experience of survival advantage in stage III and IV pancreatic cancer. Ultrasonics sonochemistry 2015; 27: 703-706

[18] Gao HF, Wang K, Meng ZQ et al. High intensity focused ultrasound treatment for patients with local advanced pancreatic cancer. Hepatogastroenterology 2013; 60: 1906-1910

[19] Lee JY, Choi BI, Ryu JK et al. Concurrent chemotherapy and pulsed highintensity focused ultrasound therapy for the treatment of unresectable pancreatic cancer: initial experiences. Korean journal of radiology: official journal of the Korean Radiological Society 2011; 12: 176-186

[20] Li J], Xu GL, Gu MF et al. Complications of high intensity focused ultrasound in patients with recurrent and metastatic abdominal tumors. World journal of gastroenterology: WJG 2007; 13: 2747-2751

[21] Li PZ, Zhu SH, He W et al. High-intensity focused ultrasound treatment for patients with unresectable pancreatic cancer. Hepatobiliary \& pancreatic diseases international: HBPD INT 2012; 11: 655-660

[22] Sung HY, Jung SE, Cho SH et al. Long-term outcome of high-intensity focused ultrasound in advanced pancreatic cancer. Pancreas 2011; 40 : $1080-1086$

[23] Wang K, Chen Z, Meng Z et al. Analgesic effect of high intensity focused ultrasound therapy for unresectable pancreatic cancer. International journal of hyperthermia: the official journal of European Society for Hyperthermic Oncology, North American Hyperthermia Group 2011; 27: $101-107$

[24] Wang K, Zhu H, Meng Z et al. Safety evaluation of high-intensity focused ultrasound in patients with pancreatic cancer. Onkologie 2013; 36: 88 92

[25] Wu F, Wang ZB, Zhu H et al. Feasibility of US-guided high-intensity focused ultrasound treatment in patients with advanced pancreatic cancer: initial experience. Radiology 2005; 236: 1034-1040

[26] Yu T, Luo J. Adverse events of extracorporeal ultrasound-guided high intensity focused ultrasound therapy. PloS one 2011; 6: e26110

[27] Orsi F, Zhang L, Arnone P et al. High-intensity focused ultrasound ablation: effective and safe therapy for solid tumors in difficult locations. American journal of roentgenology 2010; 195: W245-252 
[28] Sofuni A, Moriyasu F, Sano T et al. Safety trial of high-intensity focused ultrasound therapy for pancreatic cancer. World journal of gastroenterology: WJG 2014; 20: $9570-9577$

[29] Xiong LL, Hwang JH, Huang XB et al. Early clinical experience using high intensity focused ultrasound for palliation of inoperable pancreatic cancer. JOP: Journal of the pancreas 2009; 10: 123-129

[30] Zhao H, Yang G, Wang D et al. Concurrent gemcitabine and high-intensity focused ultrasound therapy in patients with locally advanced pancreatic cancer. Anti-cancer drugs 2010; 21: 447-452

[31] Zhao J, Zhao F, Shi Y et al. The efficacy of a new high intensity focused ultrasound therapy for locally advanced pancreatic cancer. J Cancer Res Clin Oncol 2017; 143: 2105-2111

[32] D'Onofrio M, Ciaravino V, De Robertis R et al. Percutaneous ablation of pancreatic cancer. World journal of gastroenterology: WJG 2016; 22: 9661-9673

[33] D'Onofrio M, Crosara S, De Robertis R et al. Percutaneous Radiofrequency Ablation of Unresectable Locally Advanced Pancreatic Cancer: Preliminary Results. Technology in cancer research \& treatment 2017; 16: $285-294$

[34] Lerardi AM, Lucchina N, Bacuzzi A et al. Percutaneous ablation therapies of inoperable pancreatic cancer: a systematic review. Ann Gastroenterol 2015; 28: 431-439

[35] Scheffer HJ, Vroomen LG, de Jong MC et al. Ablation of Locally Advanced Pancreatic Cancer with Percutaneous Irreversible Electroporation: Results of the Phase I/II PANFIRE Study. Radiology 2017; 282: 585-597

[36] Zhang Y, Shi J, Zeng J et al. Percutaneous Irreversible Electroporation for Ablation of Locally Advanced Pancreatic Cancer: Experience From a Chinese Institution. Pancreas 2017; 46: e12-e14

[37] Dromi SA, Walsh MP, Herby S et al. Radiofrequency ablation induces antigen-presenting cell infiltration and amplification of weak tumorinduced immunity. Radiology 2009; 251: 58-66

[38] Cantore M, Girelli R, Mambrini A et al. Combined modality treatment for patients with locally advanced pancreatic adenocarcinoma. The British journal of surgery 2012; 99: 1083-1088

[39] Frigerio I, Girelli R, Giardino A et al. Short term chemotherapy followed by radiofrequency ablation in stage III pancreatic cancer: Results from a single center. J Hepatobiliary Pancreat Sci 2013; 20: 574-577

[40] Girelli R, Frigerio I, Salvia R et al. Feasibility and safety of radiofrequency ablation for locally advanced pancreatic cancer. The British journal of surgery 2010; 97: 220-225

[41] Girelli R, Frigerio I, Giardino A et al. Results of 100 pancreatic radiofrequency ablations in the context of a multimodal strategy for stage III ductal adenocarcinoma. Langenbecks Arch Surg 2013; 398: 63 -69

[42] Matsui Y, Nakagawa A, Kamiyama Y et al. Selective thermocoagulation of unresectable pancreatic cancers by using radiofrequency capacitive heating. Pancreas 2000; 20: 14-20

[43] Spiliotis JD, Datsis AC, Michalopoulos NV et al. Radiofrequency ablation combined with palliative surgery may prolong survival of patients with advanced cancer of the pancreas. Langenbecks Arch Surg 2007; 392: $55-60$

[44] Wu Y, Tang Z, Fang H et al. High operative risk of cool-tip radiofrequency ablation for unresectable pancreatic head cancer. Journal of surgical oncology 2006; 94: 392 - 395

[45] Hamamoto S, Okuma T, Yamamoto A et al. Radiofrequency ablation and immunostimulant OK-432: combination therapy enhances systemic antitumor immunity for treatment of VX2 lung tumors in rabbits. Radiology $2013 ; 267: 405-413$

[46] Carrafiello G, lerardi AM, Fontana F et al. Microwave ablation of pancreatic head cancer: safety and efficacy. Journal of vascular and interventional radiology: JVIR 2013; 24: 1513-1520
[47] Lygidakis NJ, Sharma SK, Papastratis P et al. Microwave ablation in locally advanced pancreatic carcinoma-a new look. Hepato-gastroenterology 2007: 54: $1305-1310$

[48] Hinshaw JL, Lubner MG, Ziemlewicz TJ et al. Percutaneous tumor ablation tools: microwave, radiofrequency, or cryoablation-what should you use and why? Radiographics: a review publication of the Radiological Society of North America, Inc 2014; 34: 1344 - 1362

[49] Li J, Chen X, Yang $\mathrm{H}$ et al. Tumour cryoablation combined with palliative bypass surgery in the treatment of unresectable pancreatic cancer: a retrospective study of 142 patients. Postgraduate medical journal 2011; 87: 89-95

[50] Song ZG, Hao JH, Gao S et al. The outcome of cryoablation in treating advanced pancreatic cancer: a comparison with palliative bypass surgery alone. J Dig Dis 2014; 15: 561 - 569

[51] Narayanan G, Hosein PJ, Beulaygue IC et al. Percutaneous Image-Guided Irreversible Electroporation for the Treatment of Unresectable, Locally Advanced Pancreatic Adenocarcinoma. Journal of vascular and interventional radiology: JVIR 2017; 28: 342-348

[52] Belfiore G, Belfiore MP, Reginelli A et al. Concurrent chemotherapy alone versus irreversible electroporation followed by chemotherapy on survival in patients with locally advanced pancreatic cancer. Med Oncol 2017; 34: 38

[53] Dunki-Jacobs EM, Philips P, Martin RC 2nd. Evaluation of resistance as a measure of successful tumor ablation during irreversible electroporation of the pancreas. Journal of the American College of Surgeons 2014; 218: $179-187$

[54] Kluger MD, Epelboym I, Schrope BA et al. Single-Institution Experience with Irreversible Electroporation for T4 Pancreatic Cancer: First 50 Patients. Annals of surgical oncology 2016; 23: 1736-1743

[55] Mansson C, Brahmstaedt R, Nilsson A et al. Percutaneous irreversible electroporation for treatment of locally advanced pancreatic cancer following chemotherapy or radiochemotherapy. European journal of surgical oncology: the journal of the European Society of Surgical Oncology and the British Association of Surgical Oncology 2016; 42: 1401-1406

[56] Martin RC 2nd, Kwon D, Chalikonda S et al. Treatment of 200 locally advanced (stage III) pancreatic adenocarcinoma patients with irreversible electroporation: safety and efficacy. Annals of surgery 2015; 262: 486 494; discussion 92-94

[57] Yan L, Chen YL, Su M et al. A Single-institution Experience with Open Irreversible Electroporation for Locally Advanced Pancreatic Carcinoma. Chinese medical journal 2016; 129: 2920-2925

[58] Alagappan M, Pollom EL, von Eyben R et al. Albumin and NeutrophilLymphocyte Ratio (NLR) Predict Survival in Patients With Pancreatic Adenocarcinoma Treated With SBRT. Am J Clin Oncol 2018; 41: 242 247

[59] Chuong MD, Springett GM, Freilich JM et al. Stereotactic body radiation therapy for locally advanced and borderline resectable pancreatic cancer is effective and well tolerated. International journal of radiation oncology, biology, physics 2013; 86: 516-522

[60] Comito T, Cozzi L, Clerici E et al. Can Stereotactic Body Radiation Therapy Be a Viable and Efficient Therapeutic Option for Unresectable Locally Advanced Pancreatic Adenocarcinoma? Results of a Phase 2 Study. Technology in cancer research \& treatment 2017; 16: 295-301

[61] Dholakia AS, Chaudhry M, Leal JP et al. Baseline metabolic tumor volume and total lesion glycolysis are associated with survival outcomes in patients with locally advanced pancreatic cancer receiving stereotactic body radiation therapy. International journal of radiation oncology, biology, physics 2014; 89: 539-546

[62] Gurka MK, Collins SP, Slack R et al. Stereotactic body radiation therapy with concurrent full-dose gemcitabine for locally advanced pancreatic cancer: a pilot trial demonstrating safety. Radiat Oncol 2013; 8: 44

[63] Herman JM, Chang DT, Goodman KA et al. Phase 2 multi-institutional trial evaluating gemcitabine and stereotactic body radiotherapy for 
patients with locally advanced unresectable pancreatic adenocarcinoma. Cancer 2015; 121: 1128-1137

[64] Hoyer M, Roed H, Sengelov L et al. Phase-II study on stereotactic radiotherapy of locally advanced pancreatic carcinoma. Radiotherapy and oncology: journal of the European Society for Therapeutic Radiology and Oncology 2005; 76: $48-53$

[65] Koong AC, Le QT, Ho A et al. Phase I study of stereotactic radiosurgery in patients with locally advanced pancreatic cancer. International journal of radiation oncology, biology, physics 2004; 58: 1017-1021

[66] Mahadevan A, Jain S, Goldstein M et al. Stereotactic body radiotherapy and gemcitabine for locally advanced pancreatic cancer. International journal of radiation oncology, biology, physics 2010; 78: 735-742

[67] Mahadevan A, Miksad R, Goldstein M et al. Induction gemcitabine and stereotactic body radiotherapy for locally advanced nonmetastatic pancreas cancer. International journal of radiation oncology, biology, physics 2011; 81: e615-e622

[68] Rwigema JC, Parikh SD, Heron DE et al. Stereotactic body radiotherapy in the treatment of advanced adenocarcinoma of the pancreas. Am J Clin Oncol 2011; 34: 63-69

[69] Schellenberg D, Goodman KA, Lee F et al. Gemcitabine chemotherapy and single-fraction stereotactic body radiotherapy for locally advanced pancreatic cancer. International journal of radiation oncology, biology, physics 2008; 72: 678-686

[70] Schellenberg D, Kim J, Christman-Skieller C et al. Single-fraction stereotactic body radiation therapy and sequential gemcitabine for the treatment of locally advanced pancreatic cancer. International journal of radiation oncology, biology, physics 2011; 81: 181 - 188
[71] Song Y, Yuan Z, Li F et al. Analysis of clinical efficacy of CyberKnife((R)) treatment for locally advanced pancreatic cancer. Onco Targets Ther 2015; 8: 1427 - 1431

[72] Tozzi A, Comito T, Alongi F et al. SBRT in unresectable advanced pancreatic cancer: preliminary results of a mono-institutional experience. Radiat Oncol 2013; 8: 148

[73] Zhu X, Li F, Ju X et al. Prognostic role of stereotactic body radiation therapy for elderly patients with advanced and medically inoperable pancreatic cancer. Cancer Med 2017; 6: 2263 - 2270

[74] lerardi AM, Lucchina N, Petrillo M et al. Systematic review of minimally invasive ablation treatment for locally advanced pancreatic cancer. La Radiologia medica 2014; 119: 483 -498

[75] Salgado S, Sharaiha R, Gaidhane M et al. Ablation therapies for pancreatic cancer: an updated review. Minerva Gastroenterol Dietol 2014; 60: $215-225$

[76] Dimitrov D, Feradova H, Gincheva D et al. Ablative techniques in advanced pancreatic cancer: do they affect the quality of life?-Review. J Pancreas (online) 2015; 16: 425-431

[77] Hynynen K, Lulu BA. Hyperthermia in cancer treatment. Investigative radiology 1990; 25: $824-834$

[78] Sofuni A, Moriyasu F, Sano T et al. The current potential of high-intensity focused ultrasound for pancreatic carcinoma. Journal of hepato-biliarypancreatic sciences 2011; 18: 295-303

[79] Bjerregaard JK, Mortensen MB, Schonnemann KR et al. Characteristics, therapy and outcome in an unselected and prospectively registered cohort of pancreatic cancer patients. European journal of cancer 2013; 49: $98-105$ 